\title{
A FALTA DE SANEAMENTO E O IMPACTO AMBIENTAL EM RIOS URBANOS
}

\section{Leandro Souza de Freitas ${ }^{1}$ \\ Rachel Sampaio Oliveira ${ }^{2}$ \\ Júlio Cesar da Silva ${ }^{3}$}

Resumo: O impacto ambiental em rios traz uma preocupação com a falta d'água nos dias atuais. O rio base deste estudo é o rio Pilar localizado na Baixada Fluminense no estado do Rio de Janeiro. É cada vez maior a importância, nos dias atuais, de se buscar o uso racional da água, consciência essa já comumente disseminada no meio empresarial e entre a população, fato evidenciado pela crise hídrica vivida recentemente pela região sudeste (2014-2015). Ainda que rios, lagos e córregos abasteçam regiões inteiras e desempenhem um papel fundamental na vida de todos. A preservação dos cursos d'água no Brasil está longe de ser a ideal, embora disponham de avançado arcabouço legislativo, como por exemplo, a lei $n^{\circ}$ 9.433, de 1997. A poluição hídrica de maior representatividade em volume e carga é de natureza orgânica, principalmente por estar associada à composição dos esgotos domésticos. Este problema já está contornado em países mais desenvolvidos, mas ainda constitui o principal impacto de qualidade ambiental no Brasil.

Palavras-chave: Impacto ambiental; Preservação; Esgotos domésticos.

\footnotetext{
${ }^{1}$ Aluno do $8^{\circ}$ Período do curso de Engenharia Civil/Universidade Unigranrio, Duque de Caxias-RJ, Brasil. E-mail: leanfrei85@gmail.com.

2 Orientadora do projeto - Impacto ambiental, preservação, esgotos domésticos/Universidade Unigranrio, Duque de Caxias-RJ, Brasil. E-mail: rachelsam@bol.com.br.

3 Coordenador do curso de Engenharia Civil/Universidade Unigranrio, Duque de Caxias-RJ, Brasil. E-mail: jcesarop@unigranrio.edu.br.
} 